\title{
MUNICIPAL UNIVERSITIES OF THE UNITED STATES
}

\author{
PROF. JOHN L. PATTERSON 1 \\ Louisville, $K y$.
}

$\mathrm{T}^{\mathrm{H}}$ HE term "municipal university" is applied specifically to universities and colleges that are partly supported by taxation in the municipalities in which they are located. They are intended to complete the local public educational systems, and to give the opportunity of advanced education to the citizens in general and especially to the large class of young men and women who cannot go to college elsewhere on account of the expense of tuition and of living away from home.

Some of our modern municipal universities aim to bring about a similar result in college training, together with results broader and more important, ${ }^{2}$ by means of a system introduced a few years ago by Dean Herman Schneider, of the University of Cincinnati. This system is called "the co-operative method." According to the co-operative method the students attend lectures and recitations in the university and during alternate fortnights, under the supervision of the staff, they work for pay in the city at the application of their special subjects. The students are divided into two sections and relieve one another in the class rooms and the shops, so that the work of the college and of the employers is uninterrupted. In this way practice is taught co-ordinately with theory. The co-operative method has been used especially in engineering, but it suggests wider applications and broader fields of usefulness. The system has proved successful in the University of Cincinnati, and is being gradually adopted by the Municipal University of Akron (and by others).

All municipal universities aim to meet the increasing need of citizens trained for civic usefulness. They study the special wants of the city in which they are located, and aim to fill them by offering appropriate courses. They aim to co-operate with the various municipal departments and institutions by rendering them expert service, and by receiving corresponding benefit. They endeavor also in many other ways to bring the students and the citizens face to face with the principles taught in college and the results produced by them. At the same time, the municipal university has not abandoned loftier ideals and still offers theoretical, cultural, and artistic instruction as the frame-work of a liberal education.

${ }^{1}$ Dean, College of Arts and Sciences of the University of Louisville; president, Association of Colleges and Universities of Kentucky.

"Consult "The University and the Municipality," U. S. bureau of education, Bulletin 1915, No. 38. 
After being invited by the National Municipal Review to write an article on the municipal universities and colleges of the United States, the writer decided that in the special accounts of these institutions it would be well to have them speak for themselves. Letters were accordingly sent to them with the invitation to contribute to this symposium. The contributions appear below, but in two cases where no statements were submitted by the colleges themselves a brief description of their history and work has been prepared in the University of Louisville.

President Parke R. Kolbe of the Akron municipal university, defines a municipal university as "an institution of higher learning supported in greater part by municipal taxation, requiring graduation from a firstgrade high school for entrance, and maintaining a four-year course in arts and letters, around which a greater or less number of other schools or departments may be grouped. Its participation in technical, professional, and graduate work or in civic co-operation will naturally vary with city and institution."3 Under a strict application of this definition according to President Kolbe, there are seven municipal universities or colleges in the United States: the University of Cincinnati, the College of the City of New York, the Municipal University of Akron, Hunter College of the City of New York, Toledo University, the College of Charleston, and the University of Louisville. In the following individual accounts of the various municipal universities or colleges stress is placed on their work in its relation to the affairs and institutions of their respective municipalities. They offer in addition the usual curricula of most universities or colleges.

\section{THE UNIVERSITY OF CINCINNATI}

Buildings, bonds, and endowments have their place in the history of the University of Cincinnati, but the dominating factor in its progress has been an idea. This idea, around which the institution has grown, is that a university should be an integral part of the community life; that the citizens should think of their university along with their railroad terminals, park systems, and commercial exchanges, as part and parcel of the life and work of the municipality. This thought, always present in the institution's career, has been given conscious and energetic development during the past ten years under the present administration of the university. The aim has been to place the university in intimate relationship with the governmental, social, and industrial activities of the city, and thus, while testing and vitalizing the class-work of students and teachers, to aid in the various phases of urban life.

So, before considering the usual facts as to foundations, appropriations, and other biographical data, it may be well to instance the operation of

8 Article 2, the U. S. bureau of education, Bulletin 1915, No. 38.

${ }^{4}$ Quoted from a member of the University of Cincinnati faculty. 
this central and co-ordinating idea which President Dabney of the university terms "co-operation in service." For example, take the work of the teachers college: this college not only sets for itself the customary task of training teachers, but also that of acting as an advisory board to the superintendent of the city schools and the board of education. The faculty examines and recommends teachers for appointment and promotion, plans courses of study for the grades, and gives instruction in pedagogic methods to acting as well as to prospective teachers.

The co-operative course of the college of engineering is perhaps the most widely known phase of the university's work. Under this plan the student's time is divided between college theory and its application in various engineering establishments of the city. The students assigned to each shop are paired so that one boy works in the shop for two weeks while his companion is taking class work in the college; then, during the next two weeks, the boys exchange activities, and thus the alternation is continued throughout the session. In this way the student has training in the principles of engineering, the practical application of these principles in shop work, and an opportunity to earn in wages enough to pay a large part of his expenses. The manufacturers are emphatic in their praise of this co-operative plan, and each year there come from every section of the country twice as many applications for admission to the college as can at present be accepted.

The medical college has close connections with many departments of the city's work. It conducts a free dispensary in which over 21,000 cases are treated annually; the children's clinic of the college maintains milk supply stations and sends nurses to the tenement districts to train mothers in the care of their infants. Members of the faculty do most of the medical surgical work in seven hospitals and care for the sick and infirm at several settlements and asylums.

Other phases of co-operation which may be mentioned in this brief survey are: the work of the departments of zoology and botany with the bird reserve, grammar-school gardens, and city zoological gardens; the activities of the psychological department in diagnosing the deficiencies of backward children in the primary schools; the conduct by the political science department of a municipal reference bureau in the city hall; the service of the bureau of city tests at the university in examining all materials submitted by the city engineer and by the purchasing agent. The college of commerce holds its sessions in the late afternoon and evening, so as to serve best the young business men of the city; and the evening classes of the college of liberal arts are open to non-professional students who are unable to leave their work during the day. In addition, various classes known as external courses are held in many sections of the city. If the University of Cincinnati were to choose a word to inscribe over its entrance portals, its word of all words would be "co-operation." 
The university was established on a municipal basis in 1870; but the records of the institutions out of which the university grew go back to the very early years of the nineteenth century. 'In 1858 Charles McMicken gave to Cincinnati his estate of about a million dollars for founding two colleges for white boys and girls. Owing to a decision of the supreme court of Louisiana, a large part of this estate was lost to the city, and it was not until 1870 that the municipality incorporated the University of Cincinnati and issued bonds for the erection of a building. In 1893 the city began to tax itself to meet the current expenses of theschool by levying a university tax of three tenths of a mill, which in 1906 was increased to five tenths of a mill. The citizens of Cincinnati, moreover, have supplemented the official support of the school by private endowments, which now total over a million dollars. In this connection, public spirited Cincinnatians have organized the endowment fund association, which administers many of the private gifts to the university and undertakes to make known the needs of the institution. ${ }^{5}$

\section{THE COLLEGE OF THE CITY OF NEW YORK}

The College of the City of New York, originally called "The Free. Academy," was established in 1848 by the board of education of New York in pursuance of an act of the legislature of the state passed on May 7,1847 , and ratified by a vote of the people of the city on June 9, 1847. It is governed by a board of trustees composed of nine members appointed by the mayor. The president of the board of education is an additional. member ex-officio. The appointed members serve for nine years each.

The college is supported by the city. Tuition is absolutely free. The budget for 1916 was $\$ 696,119.07$. During the past term from October 1915 to February 1916 there were 2,699 students in the college who were doing work credited for degrees. There were also 5,165 students taking. extension courses, making a total of 7,864 students who are meeting full college entrance requirements. One thousand seven hundred and twentyone students were enrolled in the preparatory department; 338 students were enrolled in the "municipal evening session"; and 227 were enrolled for custom house courses. The grand total of students receiving organized instruction under the college was, during this term, 10,150.

The college has no graduate department, although many college graduates as special students avail themselves of its facilities for higher work. The degrees of A.B. and S.B. are granted, and graduates of the college are admitted to all higher institutions requiring the A.B. or the S.B. degree for entrance.

"See article entitled "A Study of the Student Body of the University of Cincinnati." A Municipal Institution by Pres. Charles W. Dalney, National Municipal Review, vol. iii, p. 68.

- Frederick E. Breithut, College of the City of New York. 
The most recent development of work at the college has been along the line of correlation with the needs of the municipal service, both in preparing students for entrance to the service and in improving the efficiency of those already in the city's employ. Thus the department of education supplies many of the city's teachers, and credit for work done or courses taken at the college is granted by the department of education. The department of chemistry gives work in direct co-operation with the city's laboratories. The principles embodied in such co-operation are now being extended to other city departments and other college departments. It is thus hoped that among its functions the college will become to some extent a training school for public service.

\section{THE MUNICIPAL UNIVERSITY OF AKRON ${ }^{7}$}

The nucleus for the Municipal University of Akron, which began its official existence on January 1, 1914, was Buchtel College, an institution of higher learning founded under the joint auspices of an Akron citizen, John R. Buchtel, and of the Ohio Universalist convention in the year 1870.

Statistics given in the catalogues of earlier years show that Buchtel at first drew her students largely from denominational sources, but the rapid multiplication of educational institutions in all parts of the country gradually brought about at Buchtel, as well as elsewhere, a falling off in the number of non-resident students and a corresponding increase in local attendance.

While the character of the student body was thus gradually changing from a denominational to a local predominance the financial condition of the institution was far from encouraging. Denominational support had almost entirely ceased during the last decade. At the same time the people of Akron had never come to look upon the college as entirely theirs; hence ample support from local sources was also denied. Meanwhile the constant and steady increase in the number of local students rendered the necessary financing of the college budget a more and more difficult problem for the trustees and the president to solve.

At a meeting of the Buchtel trustees, held on April 14, 1913, a proposition was laid before the board to turn over to the city of Akron the entire plant and endowment of the college, with the proviso that the purposes of all original bequests be carried out and the college be supported and administered by the city in accordance with the provisions of the state code. On August 25, 1913, the council of the city of Akron unanimously accepted by ordinance the offer of the trustees of Buchtel College and established a municipal university. The final transfer was executed on December 15, 1913.

In organization the university has very frankly copied the methods of the University of Cincinnati and accepted aid from it not only in methods,

' Parke R. Kolbe, the Municipal University of Akron. 
but also in securing from it one or two competent men for carrying out certain parts of the work planned.

When the institution was turned over to the city it consisted simply of a liberal arts college. This has been kept intact and enlarged to a considerable extent. There are two new schools. One is the college of engineering, on the co-operative plan, as introduced by Dean Schneider, of Cincinnati. Professor Ayer, who had been at Cincinnati for eight years, was appointed dean of this college. The other school is the school of home economics, with the regular four-year course and the regular fifteen-unit entrance requirement in force. The first class contained twenty women.

The students come very largely from the city itself. Out of one hundred high school graduates in Akron who entered college for the first time in the fall of 1915,75 went to the city university.

The university is trying to co-operate in various ways with the city departments. The city's testing work is carried on entirely in the laboratories of the university under the direction of a department called the bureau of city tests. Here is done the chemical testing of supplies purchased by various departments, bacteriological testing for the Board of health and local physicians, and physical testing of paving brick, cement, and so forth.

The department of political science and sociology is co-operating with the board of health and the charity organization society in using students as workers and investigators in the city; also with the bureau of municipal research in the study of city departments. One of the fields now in prospect is that of training for public service. It is hoped eventually to establish a co-operative course for this purpose in connection with the department of political science, the engineering college, and the bureau of municipal research.

A step in advance has been taken by the establishment of a combination course, in co-operation with the board of education, between the university and the city normal school for the training of teachers. Graduates of this course will receive preference in appointment to positions in the city school system.

Akron, being the center of the rubber industry, offers opportunity for specialization in the chemistry of rubber at the municipal university, which possesses the only fully equipped college laboratory for this purpose in the country.

The college of engineering is co-operating with nearly a dozen factories of the city where its students work in alternating two-week periodsalso with various contracting firms and railroads. The college has also been active in the investigation of paving conditions in the city and has published a detailed report on the subject at the request of the city council. 
Extension work is being carried on by means of a course of six lectures offered by the university faculty to a number of clubs and organizations in the city. Late afternoon and evening classes recently organized offer the opportunity for college work to teachers, employed persons, and citizens in general.

\section{HUNTER COLLEGE OF THE CITY OF NEW YORK 8}

Hunter College of the City of New York was established on February 1,1870 , and received its charter from the State in 1888 . It is a college for women and is supported by public funds. It receives as students all applicants who are residents of any of the boroughs of Greater New York, and who can meet the requirements for admission. Tuition, text-books, and other such supplies are furnished without cost to the students.

The college provides a four-year academic course which is based upon a four-year high school course and leads to the degree of A.B. One of the chief purposes of the institution is to encourage young women having a liberal college education to engage in the work of teaching in elementary and secondary schools. To this end there are provided optional courses and training in pedagogics covering the requirements for licenses to teach in the schools of both the city and the state. The degree of A.B. is conferred upon all graduates of the college. The state commissioner of education will issue to any holder of this degree who has pursued in college the prescribed course of study for the training of teachers the college graduate certificate, or temporary license to teach in the elementary or secondary schools of the state without further examination.

The history of Hunter College shows the development of free education for women in the city of New York. Beginning with a small group of elementary school graduates in one of the public schools, under the direction of Miss Lydia F. Wadleigh, the numbers increased until the Normal College of the City of New York was established in 1870 with Dr. Thomas Hunter as president. In April, 1914, eight years after the retirement of President Hunter, the name was changed from Normal to Hunter College.

At first the girls were admitted directly from elementary schools upon passing an entrance examination in algebra, arithmetic, geometry, geography, history, reading, and spelling, and the course occupied only three years. As time went on the length of the course was extended until it reached the present four-year college course based upon a four-year high school course.

Including the class of January 1916, the total number of graduates from Hunter College is 13,195. Statistics compiled from the records of several years show that 78 per cent of the graduates of Hunter College are teaching in the elementary schools of New York. Fifty per cent of the women principals in the boroughs of Manhattan and Bronx are

- Lillian M. Snow, Hunter College of the City of New York. 
Hunter College graduates, and the number teaching in the city high schools is increasing every year. The number of students in attendance at the college on February 18, 1916 was $1,627$.

\section{TOLEDO UNIVERSITY ${ }^{9}$}

The University of Toledo was first established on a municipal basis in 1884. It embraces at present the following schools: the municipal college of arts and sciences, of commerce and business, the graduate college, the college of industrial science, the college of law, and the college of pharmacy.

The various colleges of the university co-operate with the city of Toledo through the bureau of public service, the purpose of which is twofold: first, to discover the opportunities of the university for most efficient service to the community; secondly, to aid the city in offering to the university the advantages or opportunities for performing its public service most effectively. Through this bureau information is secured which enables the university to use the funds at its disposal to the best advantage.

In several departments definite efforts have been made to make the work of the university fit the needs of the city. The college of arts and sciences in its courses in education is of material assistance to the teachers of the city in their endeavor to increase their teaching efficiency. The instruction in both economics and political science aims to deal with problems arising in civic affairs. "The Government of Toledo," a course in political science, is concerned particularly with the local government. The work given in the industrial department is confined entirely to evening work and is given primarily to those men and boys who are employed during the day. The colleges of law and of pharmacy aid in securing outside employment for students who are partially dependent on their own efforts for support.

Arrangements have been made with the public library whereby the university library has been made the university branch of the public library. Students of the university have all the privileges of the main library, and the city public library maintains an excellent reference library in the university building. The library of the Lucas County court house is also open to the students of the college of law. Both the Y. M. C. A. and the Y.W. C. A. offer certain gymnasium privileges free to full time university students.

The college of arts and sciences is a vital part of the university. For the benefit of young people who are unable to complete a four-year course, the college is divided into two courses-a junior and a senior. The junior college work is almost entirely a required course, each subject of which is intended to contribute directly to increasing the social and civic

'Ruth Rose, University of Louisville. 
efficiency of the students. In the senior college the requirements are a junior college arts diploma and a major of eighteen hours and two minors of twelve hours each. The characteristic of the major is this; that the individual in addition to doing the eighteen hours of work shall also do a constructive piece of work for the municipality or shall complete a task which shall be of interest and value to the citizens of Toledo.

\section{THE COLLEGE OF CHARLESTON ${ }^{10}$}

The College of Charleston was founded in 1785 as an endowed institution, supported by donations from private citizens. The general assembly of South Carolina granted the college a charter and about nine acres of land in the central part of the city for its buildings. Throughout the early years of the history of the college there was a constant struggle for funds, which came in only through subscription and bequest. In 1837 the city of Charleston decided to assume responsibility for the necessary expenses of the college and has since that time made an annual appropriation for the college. On a board of trustees consisting of sixteen members the city has a representation of five, the alumni of the college have three representatives, and the other eight members are a part of the original self-perpetuating body which formerly governed the institution.

The College of Charleston offers annually four scholarships which carry free tuition to graduates of the high school (of Charleston) and one scholarship to some resident of each county in the state. In addition there are about fifteen paying scholarships, provided for by endowment, which are awarded on the merits of competitive examination.

\section{THE UNIVERSITY OF LOUISVILLE"}

The University of Louisville, Kentucky, was founded in 1837 by a decree of the city council, and was chartered in 1846 by an act of the legislature. Owing to local conditions, only the schools of medicine and of law were put immediately into operation. The medical department is the second oldest school of medicine now in existence west of the Alleghanies. By the coalition, under the name "University of Louisville," of the schools of medicine of Louisville, embracing the medical department of the University, organized in 1837, the Kentucky School of Medicine, 1850, the Louisville Medical College, 1869, the Hospital College of Medicine, 1873, and the Medical Department of the Kentucky University (now Transylvania College), 1898, new property, greater prestige, and wider influence were added to the University of Louisville, thus making it a strong one of its class, and promising for the future the maintenance of increasingly higher standards to satisfy the increasing

10 Mary Campbell Kahn, University of Louisville.

11 In this description of the University of Louisville the writer has copied freely from articles which he has written on other occasions. 
requirements demanded by the state medical boards. Substantial additions have also been made recently to the laboratories and clinical facilities.

A new hospital was completed a few years ago by the City of Louisville at a cost of a million dollars. It has been made a teaching hospital under the advice of one of the best hospital experts in the country. The medical management of the hospital has been placed by the mayor in the hands of the board of trustees of the University of Louisville. They select the staff and recommend it to the mayor and board of public safety for appointment. The medical department has again (1916) been placed in Class $\mathrm{A}$ by the council on medical education of the American Medical. Association.

The law department of the university is, with one exception, the oldest. law school in the South. It has graduated about 1,400 students, many of whom are practicing their profession or fllling offices of public trust in most of the states of the union. Recently the corps of instructors has been increased, and the mode of teaching has been supplemented by the best modern methods employed at Harvard, Columbia, and other universities of prominence.

The college of arts and sciences was added to the university in 1907 to. carry out the founders' original design of establishing "departments for the promotion of science, literature, and the liberal arts." The attempt is being made to develop the university as a municipal institution which will co-operate in due time with the various departments and public institutions of Louisville, and offer the opportunity of advanced education. to the sons and daughters of its citizens. The university has been influenced in this work by the example of the municipal universities in England and in this country, and especially by the brilliant one of the University of Cincinnati.

The college of arts and sciences co-operates with the board of education. of Louisville, and offers the S.B. degree in education for a prescribed course. of study pursued in the college, together with complementary technical work done in the public normal school. An arrangement was made in. 1914 with the Board of Education by which graduates of the university (of Louisville), under the conditions mentioned, in regard to appointments are entitled to "the same privileges accorded to a holder of a diploma. from the Louisville normal school." The college further co-operates. with the board by giving this year a series of free lectures on educational. psychology, mathematical pedagogy, the history of mathematics, and the history of the drama to large classes of public school teachers.

In the second place, the college co-operates with the Baptist and the. Presbyterian theological seminaries, which are located in Louisville, by offering to their students free tuition in the undergraduate courses. Theseminaries extend similar privileges to undergraduate students in the: 
college of arts and sciences. The college stands ready to co-operate in the same way with any local religious institution of collegiate grade. It co-operates also with the various religious orders of the city without discrimination of creed, and offers to their members free tuition toward the baccalaureate degree.

In the third place, the college co-operates with the Louisville chapter of the American Institute of Architects by offering courses in architectural design and the history of architecture to young men who are employed in the offices of the local architects, and so gives them the opportunity of becoming more than draughtsmen. In the fourth place, the university co-operates with the hospitals in Louisville by offering at a minimum tuition fee to the nurses from time to time night courses in physiology, hygiene, and bacteriology. In the fifth place, the college co-operates with the associated charities of Louisville, and offers also at a minimum tuition fee instruction in theoretical and practical sociology to those engaged in the work of charity and social service in the city. In the sixth place, with the co-operation of certain business houses, the college has secured this year employment for a part of their time for a few young men and women who are pursuing their regular studies in the university and who could not continue their work without financial aid. The administration expects to extend its plans of co-operation as rapidly as may be.

The college of arts and sciences has grown from a college of about 75 students to a college of 406 students at the present time-an increase of 440 per cent in eight years. The trustees, as soon as the accommodations are adequate and the funds sufficient, will offer free tuition in the college to all graduates of the local public high schools. The free tuition at present is limited to about forty scholarships. The university has a total enrollment this year of 614 students.

With the endorsement of the present mayor, John H. Buschemeyer, the public spirited administration, the representatives of Jefferson county, the board of trade, the board of education, the commercial club, the public library, members of the press, the clergy, and other clubs and organizations of Louisville, a bill has just been passed by the state legislature enabling the general council of the City of Louisville to levy a tax annually with a maximum rate of three cents for the support of its university. The bill was passed unanimously by both houses and became a law by the signature of Governor Stanley on Friday, March 24, 1916.

The ultimate authority of the university is vested in a body appointed by the city council on the recommmendation of the mayor. These men are among the most prominent citizens of Louisville, and under their direction it is reasonable to expect that the university will develop more and more successfully. At the same time the successive city administrations of Louisville, without regard to politics, have taken an increasing 
interest in the home institution, and with the influence and support of a great city behind it, the university has a promising outlook for the future.

From the above accounts of American municipal universities, it will be seen that they are proceeding on the principle that if education is a public utility, it is undemocratic for any part of it to exist in the nature of a monopoly. The modern movement in this country and abroad to develop municipal universities offering the full benefit of advanced education to all classes of citizens alike marks a new era of wider training, and therefore, of more efficient citizenship, sounder morality, and a more certain civilization. 